\title{
Influence of Co-substrates for the Methane Production Rate Kinetics in Anaerobic Fermentation of Pig Slurry
}

\author{
Karlygash Korazbekova ${ }^{1}$, Zhumabek Bakhov ${ }^{1} \&$ Botagos Mutaliyeva ${ }^{1}$ \\ ${ }^{1}$ M.Auezov South Kazakhstan State University, Kazakhstan \\ Correspondence: Karlygash Korazbekova, Department of Biotechnology, M.Auezov South Kazakhstan State \\ University, Shymkent, Kazakhstan. Tel: 7-701-662-3483. E-mail: swallow0101@mail.ru
}

Received: December 3, 2014

Accepted: January 4, 2015 Online Published: May 30, 2015

doi:10.5539/mas.v9n6p217

URL: http://dx.doi.org/10.5539/mas.v9n6p217

\begin{abstract}
The influence of co-substrates on kinetics of methane production in anaerobic fermentation of pig slurry was studied by performing a series of laboratory experiments using food waste and biowaste as co-substrates. Experiments were performed in the laboratory reactors of «Hohenheim» biogas testing system in batch mode at the temperature of $37^{\circ} \mathrm{C}$. Given $40 \mathrm{~g}$ of fresh pig slurry was fed to each digester and mixed with co-substrates in the ration of $55: 45 \%$ by organic dry matter content. Methane production rate was used to evaluate co-digestion of pig slurry. Research results showed that co-substrates gave significant effect to methane production kinetics. The kinetic parameters of methane production i.e. potential yield of methane $(\mathrm{P})$, maximum methane yield rate $\left(\mathrm{R}_{\mathrm{m}}\right)$ and duration of lag-phase $(\lambda)$ were analyzed using modified Gompertz equation. Technical time to produce $95 \%$ of potential methane yield was investigated and efficient period of anaerobic digestion was calculated. The potential production of methane was reached in lag-phase duration $(\lambda)$ of 10-13 days. Maximal methane production rate was reduced 2-3 times in co-digestion than in mono-digestion of pig slurry. The potential yield of methane (P) was $0.420 \mathrm{Nm}^{3}(\mathrm{~kg} \mathrm{oDM})^{-1}, 0.246 \mathrm{Nm}^{3}\left(\mathrm{~kg} \mathrm{oDM}^{-1}\right.$ and $0.198 \mathrm{Nm}^{3}(\mathrm{~kg} \mathrm{oDM})^{-1}$ in mono-digestion and co-digestion of pig slurry with food waste and biowaste, respectively.
\end{abstract}

Keywords: anaerobic digestion, methane production kinetics, co-digestion, biowaste, food waste

\section{Introduction}

Anaerobic digestion (AD) is one of the most effective and alternative methods of organic wastes treatment from agriculture and food industry that was used for many years result in improvement of waste stabilization, pollution control, manure quality producing fertilizer and biogas production (Weiland, 2006). Martins das Neves et al. (2009) pointed biogas as a renewable energy source produced by a large number of anaerobic microorganisms consortia and AD process is characterized by a series of biochemical transformations (Fantozzi \& Buratti, 2009). Four groups of microorganisms take place in methane fermentation creating syntrophic interrelation and requiring different environmental conditions in separate phases of anaerobic digestion indicated as hydrolysis, acidogenesis, acetogenesis and methanogenesis (Deublein \& Steinhauser, 2008; Weiland, 2010). Anaerobic microorganisms affect to specific components of the substrate selectively performing their transformation only under certain conditions during interconnected in series and parallel biochemical reactions (Gerber \& Span, 2008; Liu et al., 2009). The final product of an anaerobic fermentation is biogas that is mainly composed of $48-65 \%$ methane and $36-41 \%$ carbon dioxide, and methane is physically characterized as taste-, color-, odorless and inflammable gas that has heat value of $35.800 \mathrm{~kJ} \mathrm{~m}^{-3}$ (Martins das Neves et al., 2009).

A balanced anaerobic digestion of biomass is affected by the types of substrates and the ratio of nutrients C:N:P. In generally, all types of biomass can be used as substrates since they contain carbohydrates, proteins, fats, cellulose and hemicelluloses (Deublein \& Steinhauser, 2008; Weiland, 2010; Ward et. al., 2008). Furthermore, co-substrates content has a significant impact for the methane formation. Intermediate degradation products of anaerobic digestion can restrict and inhibit degradation depending on the composition of the substrates. For example, the degradation of fats may lead to an increase of fatty acids limiting further degradation. Methane fermentation can be limited by formation of ammonia and hydrogen sulfide in the protein decomposition (Deublein \& Steinhauser, 2008).

Weiland (2006) noted that the mono-fermentation of manure resulted in relatively low biogas yields, but it has one reliable advantage of process stability due to its high buffering capacity and its high content of trace 
elements (Weiland, 2006). Therefore, most of researchers interested in co-fermentation of manure together with non-agricultural organic wastes, harvesting residues, energy crop, food industry wastes, biowastes in order to increase biogas yield (Liu et al., 2009; Ward et. al., 2008; Alatriste-Mondragon et. al., 2006; Labatut \& Scott, 2008; Korazbekova et. al., 2012). Numerous models were developed that take into account the biological and physico-chemical basis of anaerobic fermentation and the growth kinetics of methanogenic microorganisms to evaluate overall performance of anaerobic digestion (Lay et. al., 1998; Koppar \& Pullammanappallil, 2008; Lo et. al., 2010). The kinetic parameters of methane production facilitate the understanding of the methanogenesis process and optimization of biogas plants.

Influence of co-substrate such as biowaste and food waste on the decomposition of pig slurry in terms of the kinetics of methane production was studied in order to evaluate co-digestion of pig slurry and to describe anaerobic digestion defined as methanogens growth rate.

\section{Materials and Methods}

\subsection{Substrates and Sample Preparation}

Potential methane yield from mono-digestion and co-digestion of liquid manure from pigs (pig slurry) was studied in combination with food waste and biowaste. Samples of pig slurry were taken from the farm of the University of Hohenheim. Food waste (leftovers) was provided by the university canteen; biowaste was obtained from the laboratory of the university, which was mixture of different wastes (vegetable waste, food waste, paper waste, etc) taken from landfill previously separated from undecomposable parts (metal, stone, plastic). All substrates as fresh material (FM) have been examined in triplicate for dry matter (DM), organic dry matter (oDM), ash and moisture content, because, they are main parameters for the evaluation of methane yield and degree of organic substances decomposition. These indicators were analyzed according to APHA (1995) by drying at the $105^{\circ} \mathrm{C}$ for $12 \mathrm{~h}$ and burning at the $505^{\circ} \mathrm{C}$ for at least $6 \mathrm{~h}$ in oven. The results of DM, oDM, ash and moisture content definitions of tested substrates are shown in Table 1.

Table 1. Results of the substrate analysis

\begin{tabular}{lllll}
\hline \multirow{3}{*}{ Substrate samples } & \multicolumn{3}{l}{ Parameters $(\%)^{\mathrm{a}}$} & \\
\cline { 2 - 5 } & $\begin{array}{l}\text { Dry matter } \\
\text { content of fresh } \\
\text { material }\end{array}$ & $\begin{array}{l}\text { Organic dry matter } \\
\text { content of dry matter }\end{array}$ & $\begin{array}{l}\text { Ash content of fresh } \\
\text { material }\end{array}$ & $\begin{array}{l}\text { Moisture } \\
\text { content }\end{array}$ \\
\hline Liquid manure from pigs & $2.11 \pm 0,03$ & $66.15 \pm 0.850$ & $0.72 \pm 0.020$ & 97.89 \\
Food waste (leftovers) & $18.94 \pm 0.15$ & $91.20 \pm 0.023$ & $1.67 \pm 0.009$ & 81.06 \\
Biowaste & $95.48 \pm 0.05$ & $84.12 \pm 0.400$ & $15.16 \pm 0.390$ & 4.52 \\
\hline
\end{tabular}

${ }^{\mathrm{a}}$ Data expressed as the Mean \pm SD of triplicate samples.

Biowaste was used as dry solid substrate that had the average content of DM $89.9 \pm 0.05 \%$. The content of DM in the food waste was $18.9 \pm 0.15 \%$, while the moisture content was $81.06 \%$. The highest content of oDM in DM was recorded in the substrates of food wastes. Mineral content (ash) was less than $2 \%$ in pig slurry and food waste, but biowaste has $15.16 \pm 0.390 \%$ of mineral content.

Pig manure (sample 1) was used in the amount of about $40 \mathrm{~mL}$ of the substrate for mono-fermentation, and 30 $\mathrm{mL}$ of the substrate for co-fermentation of pig manure (samples 2 and 3) with other wastes. Ratio of tested substrates in a mixture was 55:45 by content of oDM. The complete characterization of samples is shown in Table 2.

Table 2. Features of experimental samples

\begin{tabular}{ccccccc}
\hline & Substrates & $\begin{array}{c}\text { Fresh matter } \\
\text { content } \\
(\mathrm{g})^{\mathrm{a}}\end{array}$ & $\begin{array}{c}\text { Average content } \\
\text { of dry matter } \\
(\mathrm{g})^{\mathrm{a}}\end{array}$ & $\begin{array}{c}\text { Average content of } \\
\text { organic dry matter } \\
(\mathrm{g})^{\mathrm{a}}\end{array}$ & $\begin{array}{c}\text { Moisture } \\
\text { content } \\
(\%)\end{array}$ & $\begin{array}{c}\text { Ratio of substrates } \\
\text { (by organic dry } \\
\text { matter) }\end{array}$ \\
\hline 1 & Liquid pig manure & $40.1 \pm 0.079$ & $847 \pm 0.002$ & $561 \pm 0.001$ & 97.89 \\
2 & Liquid pig manure & $32.2 \pm 0.188$ & $1018 \pm 0.004$ & $768 \pm 0.003$ & 96.84 & $55: 45$
\end{tabular}


+ food waste

3 Liquid pig manure

$30.6 \pm 0.176$

$1020 \pm 0.004$

$743 \pm 0.002$

96.66

$55: 45$ + biowaste

${ }^{a}$ Data expressed as the Mean \pm SD of three samples.

\subsection{Experimental Set-Up}

Laboratory experiments were carried out at the $37^{\circ} \mathrm{C}$ in «Hohenheim» biogas yield testing system in the biogas laboratory of the University of Hohenheim, Germany. This biogas yield testing system consists of fermenters in the form of glass syringes (flasks for sampling) of $100 \mathrm{~mL}$ with $1 / 1$ gradation and capillary extension (Figure 1), fermentation chamber - incubator (Figure 2) and gas transducer (Helffrich \& Oechsner, 2003; Ohl, 2011).

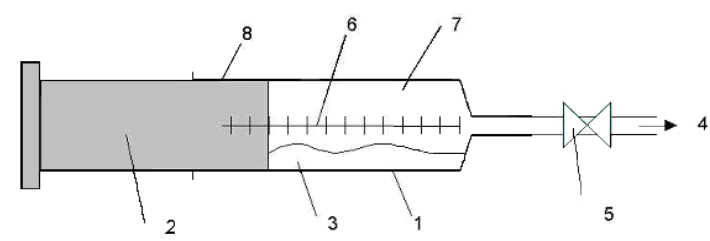

Figure 1. Laboratory mini-reactor of «Hohenheim» biogas yield testing system (Helffrich \& Oechsner, 2003)

(1) Glass syringe, (2) Stopper, (3) Substrate, (4) Hole for gas analysis, (5) Clamp for the tube, (6) Graduations, (7) Gas space, (8) Grease

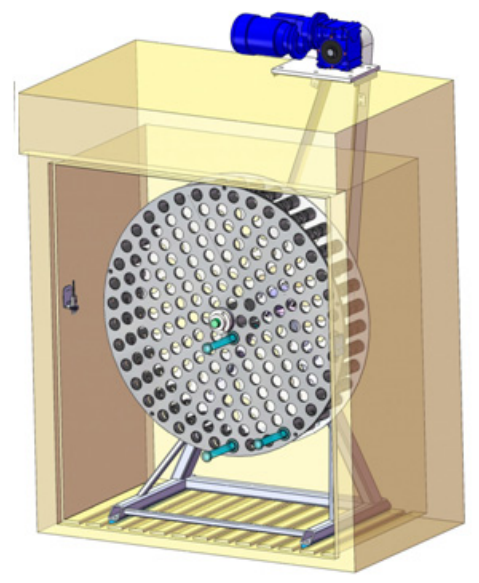

Figure 2. Schematic incubator of «Hohenheim» biogas yield testing system $(\mathrm{Ohl}, 2011)$

The methane content was measured by AGM 10 gas transducer (transducers of Europe GmbH, Germany) with a non-dispersive infrared (NDIR) detector capable of detecting methane content of the biogas in the range from 0 to $100 \%$. Gas sensor was calibrated by the standard gas, containing $60.7 \%$ (v) methane. Incubator temperature, air pressure, date and time at which the measurements were made, were also recorded for analysis of biogas content at the standard conditions (273 K and $101325 \mathrm{~Pa}$ ) determined in accordance with Ludington (2006).

\subsection{Data Analysis}

Methane production kinetics was studied for the description and evaluation of methanogenesis during anaerobic digestion of pig slurry by fitting the experimental data of cumulative methane production to the Gompertz equation that was used by Lay et al. (1998), Koppar \& Pullammanappallil (2008), Lo et al. (2010), Budiyono et al. (2010), Xie (2012) and Korazbekova et al. (2013). Data analyses of the experimental results and calculations were performed in MS-Excel using the 'Solver' feature by non-linear regression. Lay et al. (1998) and Koppar \& Pullammanappallil (2008) mentioned that this equation is suitable for description of the total methane production in batch reactors assuming that methane production is a function of methanogenic bacteria growth. The modified Gompertz equation is presented below: 


$$
M=P \times \exp \left\{-\exp \left[\frac{R_{m} \times e}{P}(\lambda-t)+1\right]\right\}
$$

where, $M$ is the cumulative methane production $\left(\mathrm{Nm}^{3}(\mathrm{~kg} \mathrm{oDM})^{-1}\right), P$ is the methane production potential

$\left(\mathrm{Nm}^{3}(\mathrm{~kg} \mathrm{oDM})^{-1}\right), R_{m}$ is the maximum methane production rate $\left(\mathrm{Nm}^{3}(\mathrm{~kg} \mathrm{oDM})^{-1} \mathrm{day}^{-1}\right), \lambda$ is the duration of lag phase (days), $t$ is the cumulative time for methane production (days). Also, the values of the parameters that minimize the sum of squared deviations between the necessary and the experimental data were determined.

\section{Results}

\subsection{Methane Production Rate}

Specific cumulative methane yield per $\mathrm{kg}$ of oDM in the normal condition (273 K and $1013.25 \mathrm{~Pa}$ ) was obtained and calculated according to the results of "Hohenheim" biogas yield testing system to evaluate methane yield potential of pig slurry in terms of methane production kinetics. Anaerobic fermentation lasted 35 days at the temperature of $37^{\circ} \mathrm{C}$ in batch mode reactors. Cumulative methane production was calculated by summing daily methane yield.

From Figure 3 can been seen similar variation of methane production rate for all three samples. Daily volume of methane was identified in the amount of $0.006 \mathrm{Nm}^{3}\left(\mathrm{~kg} \mathrm{oDM}^{-1} \mathrm{day}^{-1}\right.$ to 3-4 days and the slow gradual rise of the daily production of methane was found up to the $30^{\text {th }}$ day, showing a peak in the $29^{\text {th }}$ day in a volume of 0.069 $\mathrm{Nm}^{3}(\mathrm{~kg} \mathrm{oDM})^{-1}$ for sample $1,0.054 \mathrm{Nm}^{3}(\mathrm{~kg} \mathrm{oDM})^{-1}$ for sample 2 and $0.044 \mathrm{Nm}^{3}(\mathrm{~kg} \mathrm{oDM})^{-1}$ for sample 3 . After 30 days the daily methane production was dropped sharply to $0.02 \mathrm{Nm}^{3}\left(\mathrm{~kg} \mathrm{oDM}^{-1}\right.$ and followed by rapid growth in the sample 1. In all experimental curves of three samples was shown a rapid initial methane yield due to readily biodegradability of the substrates, it was followed by continuous increasing of methane generation until achieving the peak and then began to decline as also was presented in the research of Li et al. (2011).

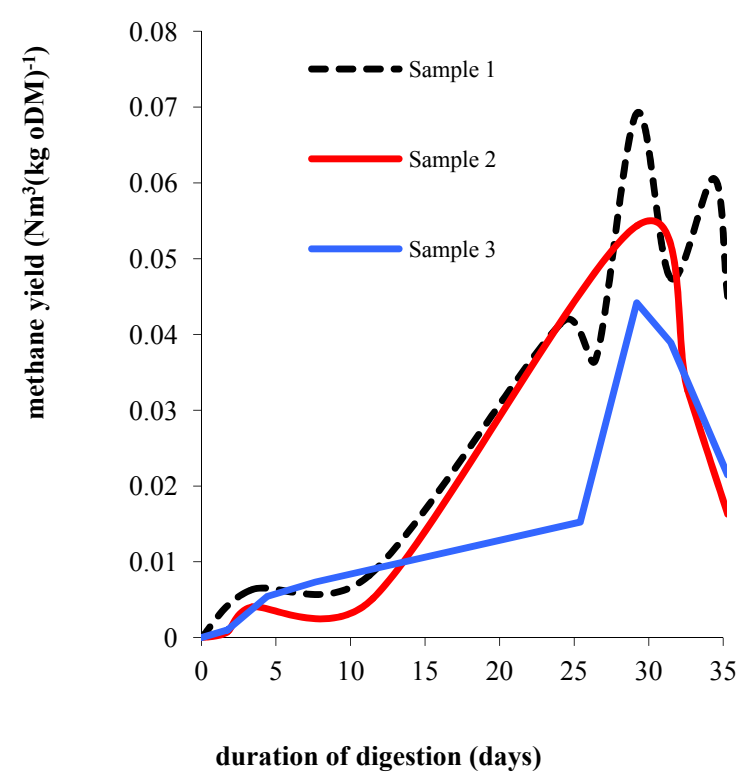

Figure 3. Daily methane production rate (on average)

The maximum daily production of methane was observed in 20-25 days after the start of anaerobic fermentation for all experiments with liquid pig manure. Mono-fermentation of liquid pig manure (sample 1) showed a higher methane yield (specific methane yield was $0.275 \mathrm{Nm}^{3}\left(\mathrm{~kg} \mathrm{oDM}^{-1}\right.$ with a standard deviation of $0.049 \mathrm{Nm}^{3}(\mathrm{~kg}$ $\left.\mathrm{oDM})^{-1}\right)$ than in samples 2 and 3, respectively $0.102 \pm 0.006 \mathrm{Nm}^{3}(\mathrm{~kg} \mathrm{oDM})^{-1}$ and $0.121 \pm 0.011 \mathrm{Nm}^{3}(\mathrm{~kg} \mathrm{oDM})^{-1}$. The percentage of methane was increased until the end of 35 days of HRT to $77.8 \%$ in the experiments with liquid pig manure. The maximum methane content was $70.9 \%$ (on $33^{\text {th }}$ day) and $70.5 \%$ (on $32^{\text {nd }}$ day) respectively in samples 2 and 3 (Figure4). Given features of methane content in Figure 4 and Table 3 represented 
low initial methane percentage associated with the biochemical transformation of organic matter in anaerobic digestion. In the second stage of anaerobic digestion (acidogenesis) 70\% of low molecular weight compounds, such as simple sugars, amino acids and fatty acids was decomposed to acetate, carbon dioxide and hydrogen, and the remaining 30\% to volatile fatty acids (VFA) and alcohols (Li et al., 2011; Seadi et al., 2008). In addition, the regeneration time of acidogenic bacteria (Bacterioids, Clostridia) is 24-36 h (Deublein \& Steinhauser, 2008).
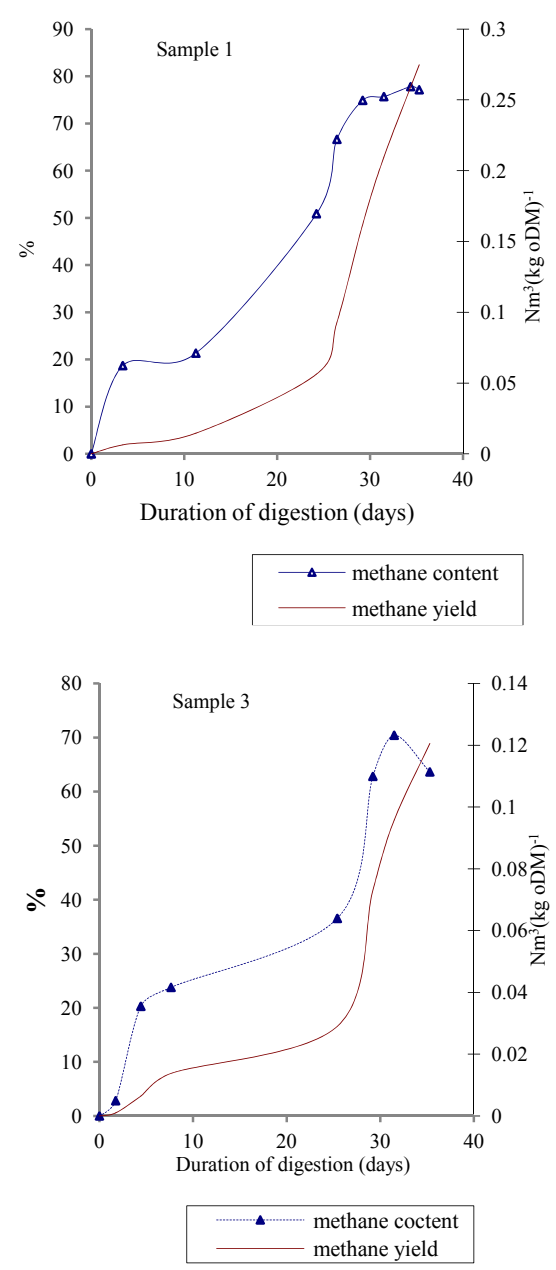

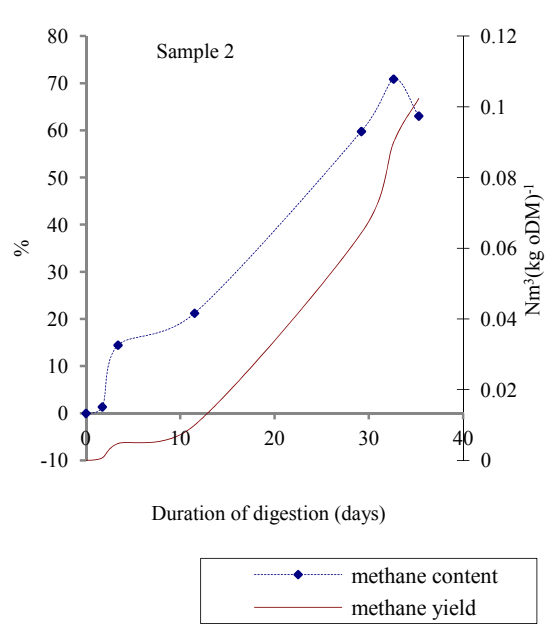

Figure 4. Cumulative methane production and methane content (\%) for samples 1-3

Table 3. Final data of potential biogas yield ${ }^{\text {a }}$

\begin{tabular}{clccc}
\hline Sample & Substrates & $\begin{array}{c}\text { Biogas yield } \\
\left(\mathrm{Nm}^{3}(\mathrm{~kg} \mathrm{oDM})^{-1}\right)\end{array}$ & $\begin{array}{c}\text { Methane content } \\
(\text { average }) \\
(\%)\end{array}$ & $\begin{array}{c}\text { Methane yield } \\
\mathrm{Nm}^{3}(\mathrm{~kg} \mathrm{oDM})^{-1}\end{array}$ \\
\hline 1 & Liquid pig manure & $0.444 \pm 0.055$ & $61.5 \pm 3.32$ & $0.275 \pm 0.049$ \\
2 & $\begin{array}{l}\text { Liquid pig manure } \\
+ \text { food waste } \\
\text { Liquid pig manure } \\
\text { + biowaste }\end{array}$ & $0.253 \pm 0.009$ & $40.3 \pm 1.06$ & $0.102 \pm 0.006$ \\
\hline
\end{tabular}

${ }^{\mathrm{a}}$ Data expressed as the Mean $\pm \mathrm{SD}$ of three samples.

\subsection{Kinetic Parameters of Methane Production}

Results of the analysis of the kinetic parameters $P, R_{m}$ and $\lambda$ are shown in Table 4 and Figure 5. Application of 
food waste and biowaste as additives to pig slurry does not provide good kinetic parameters that could improve the kinetics of co-fermentation of pig slurry in the ratio of the tested substrate composition by oDM content of 55:45. The calculation results of the kinetic parameters of methane production for sample 1 showed the following constants: the potential methane yield (P) was $0.420 \pm 0.069 \mathrm{Nm}^{3}(\mathrm{~kg} \mathrm{oDM})^{-1}$ with a standard error of $0.040 \mathrm{Nm}^{3}(\mathrm{~kg} \mathrm{oDM})^{-1}$. Duration of lag phase $(\lambda)$ was on average $12.2 \pm 1.71$ days (standard error $=0.987$ ). Average maximum rate of methane production $\left(\mathrm{R}_{\mathrm{m}}\right)$ was $0.013 \pm 0.002 \mathrm{Nm}^{3}(\mathrm{~kg} \mathrm{oDM})^{-1} \mathrm{day}^{-1}$. As seen from Table 4, P for the sample 2 was $0.246 \pm 0.016 \mathrm{Nm}^{3}\left(\mathrm{~kg} \mathrm{oDM}^{-1}\right.$ and sample 3 showed lower final methane yield of $0.198 \pm 0.010 \mathrm{Nm}^{3}(\mathrm{~kg} \mathrm{oDM})^{-1}$ that exceeds cumulative methane yield to $0.077 \mathrm{Nm}^{3}(\mathrm{~kg} \mathrm{oDM})^{-1}(39 \%)$. The potential methane yield exceeds the cumulative methane yield at $0.144 \mathrm{Nm}^{3}\left(\mathrm{~kg} \mathrm{oDM}^{-1}\right.$. Maximum methane production rate $\left(\mathrm{R}_{\mathrm{m}}\right)$ of co-digestion was 0.004 and $0.005 \mathrm{Nm}^{3}(\mathrm{~kg} \mathrm{oDM})^{-1} \mathrm{day}^{-1}$, respectively for sample 2 and 3 . It was 4.4 times lower than in mono-digestion of pig slurry (sample 1). Minimum time for methane formation was indicated as $12.40 \pm 0.85$ days in sample 2 and $10.43 \pm 1.03$ days in sample 3 . For the sample 2 need more 90 days to achieve $95 \%$ of the potential methane production, and the calculated effective period value was 78.75 days for sample 2. Duration for $95 \%$ of the potential methane yield was 67.25 days ( $\mathrm{SD}=5.19$ days), and the effective period of the production of methane was calculated as 56.82 days in co-digestion of the pig slurry with biowaste (sample 3).

Comparing the experimental and simulated cumulative graphs of methane production based on the Gompertz equation, there are can be seen the roughness in the production of methane, especially in the graphs of experimental data for sample 3. It is found sharp bends during fermentation associated with the chemical composition of co-substrates (Figure 5).

Table 4. Results of the kinetic analysis of methane production (average data)

\begin{tabular}{cccccc}
\hline Sample & $\begin{array}{c}\text { Cumulative } \\
\text { methane yield, } \\
N m^{3} / \mathrm{kg} o D M\end{array}$ & \multicolumn{2}{c}{ Gompertz parameters (model) } & \multicolumn{2}{c}{$\begin{array}{c}\text { Duration to produce } 95 \% \\
\text { potential methane yield, } \\
\text { days }\end{array}$} \\
\cline { 3 - 6 } & & $\begin{array}{c}P, \\
N m^{3} / \mathrm{kg}^{\prime} o D M^{-1}\end{array}$ & $\mathrm{Nm}^{3} / \mathrm{kg} \mathrm{oDM}^{-1}$ day $^{-1}$ & $\begin{array}{c}\lambda, \\
\text { Days }\end{array}$ & \\
\hline 1 & $0.275 \pm 0.049$ & $0.420 \pm 0.069$ & $0.013 \pm 0.0020$ & $12.20 \pm 1.71$ & $60.41 \pm 2.01$ \\
2 & $0.102 \pm 0.006$ & $0.246 \pm 0.016$ & $0.004 \pm 0.0003$ & $12.40 \pm 0.85$ & $91.15 \pm 1.79$ \\
3 & $0.121 \pm 0.011$ & $0.198 \pm 0.010$ & $0.005 \pm 0.0003$ & $10.43 \pm 1.03$ & $67.25 \pm 5.19$ \\
\hline
\end{tabular}

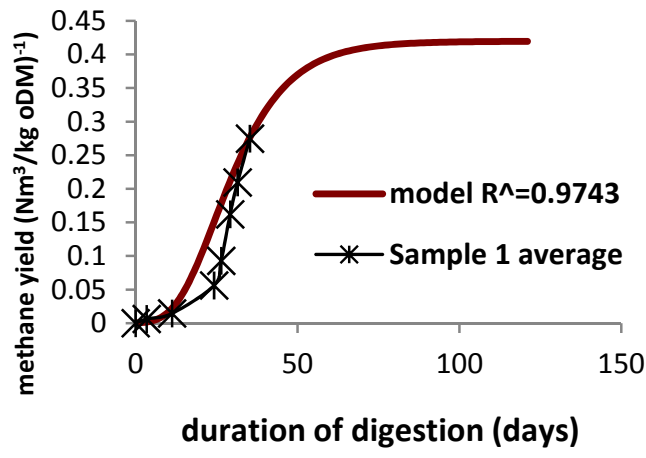

duration of digestion (days)

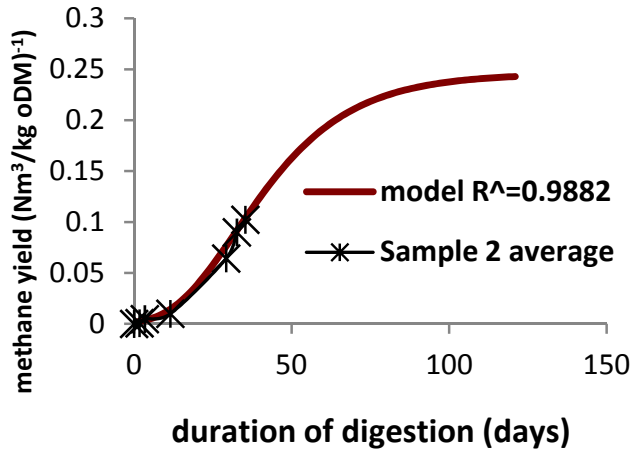




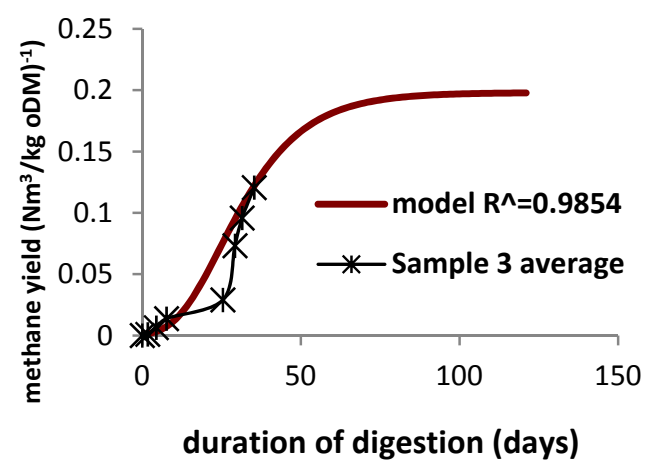

Figure 5. Comparison of potential methane yield and duration of methane fermentation using the Gompertz equation model (mean values of samples)

\section{Discussion}

Samples with a mixture of food waste and biowaste have uneven methane production, due to rapidly degradable organic substances content, which leaded to increased ammonia content causing inhibition of digestion. According to the models based on the calculated data of the kinetic model of Gompertz equation, asymptotic approximation of the cumulative methane production can not be observed. Therefore, anaerobic digestion process was modeled on the basis of the kinetic parameters. So the duration of the fermentation was not enough for all samples in 35 days, it means neediness in renew it. Anaerobic digestion of substrates depends on the structure of its components. Sugars and starches are broken down very quickly having a simple structure and requiring only a short residence time. Depending on structure complexity of the substrate, the degradation time is degrading longer. Cellulose and hemicelluloses are well structured and decomposed slowly. Lignin is decomposed very badly by bacteria, because it shows strength even to acids (Deublein \& Steinhauser, 2008). Biowaste contains vegetable waste, food waste, paper and other wastes (Deublein \& Steinhauser, 2008) which consist of easily and hardly decomposable organic compounds with up to $84 \%$ of oDM. And the food waste has more easily decomposable substances (sucrose, fructose, fatty acids, etc.). In the first phases of methane generation of hydrolysis and acidogenesis, readily degradable substances are quickly converted to the monomers, therefore the overall acid content in the medium is increased, and thereby $\mathrm{pH}$ is decreased. $\mathrm{pH}$ reduction leads to the acidaccumulation result in inhibition of methanogenesis, since easily digestible compounds of organic matter is hydrolyzed and quickly transformed into fatty acids and it will be stabilized by the VFAs consumption result in methane generation ( $\mathrm{Li}$ et al., 2011). Generally the methane formation occurs in a relatively narrow range of $\mathrm{pH}$ from about $6.5-8.5$ with an optimal range between 7.0 and 8.0 as noted by Weiland (2010) and Ahn et al. (2010). Methane production during co-digestion of pig slurry with food waste (leftovers) and biowaste was lower than in mono-digestion due to the rapid hydrolysis and acidogenesis and composition of co-substrates. Initiation of methanogenesis is inhibited and required further digestion of these substrates longer than 35 days as a result of the acid accumulation.

Duration of fermentation is one of the key indicators for evaluation of the performance of anaerobic digestion because it describes the biodegradability and the treatment rate of the substrate (Xie, 2012). Since the cumulative methane production curve only asymptotically approaches methane yield the reactor will take infinite time to produce $100 \%$ of methane potential (Koppar \& Pullammanappallil, 2008). Therefore, the $95 \%$ value was arbitrarily chosen as technical digestion time (T95). The technical digestion time described with T95 is defined as the time needed to produce $95 \%$ of the maximum methane production. And Xie (2012) reported that after subtracting the lag time $(\lambda)$ from T95, the effective methane production period can be determined. Accordingly the Gompertz equation the calculated effective duration of methane production was 78.75 and 56.82 days, respectively, for samples 2 and 3 . These values indicated that the co-fermentation of the pig slurry is longer by 30.54 and 8.61 days than mono-digestion of the pig slurry. According to the other researchers, performance of anaerobic mono-digestion and co-digestion of the pig slurry with different food waste, potato processing waste, slaughterhouse wastewater and energy plants are indicated $0.022-0.420 \mathrm{Nm}^{3}(\mathrm{~kg} \mathrm{oDM})^{-1}$ at mesophilic operation (Hansen et al., 1998; Amon et al., 2006; Monou et al., 2008; Ferrer et al., 2008). 
It can be concluded in accordance with the research results, the following kinetic parameters of the Gompertz equation for mono-fermentation of the pig slurry were obtained: $0.420 \mathrm{Nm}^{3}(\mathrm{~kg} \mathrm{oDM})^{-1}(\mathrm{P}), 0.013 \mathrm{Nm}^{3}(\mathrm{~kg}$ $\mathrm{oDM})^{-1}$ day $^{-1}\left(\mathrm{R}_{\mathrm{m}}\right)$ and 12.20 days $(\lambda)$. Co-digestion of pig slurry with food waste gave the following indicators of $0.246 \mathrm{Nm}^{3}(\mathrm{~kg} \mathrm{oDM})^{-1}(\mathrm{P}), 0.004 \mathrm{Nm}^{3}\left(\mathrm{~kg} \mathrm{oDM}^{-1} \mathrm{day}^{-1}\left(\mathrm{R}_{\mathrm{m}}\right)\right.$ and 12.40 days $(\lambda)$. Potential methane yield was $0.198 \mathrm{Nm}^{3}(\mathrm{~kg} \mathrm{oDM})^{-1}$ for co-fermentation of the pig slurry with biowaste. In general, studies showed that the kinetics of methane production depends on the biochemical transformations in the anaerobic fermentation of biomass.

\section{References}

Ahn, H. K., Smith, M. C., Kondrad, S. L., \& White, J. W. (2010). Evaluation of biogas production potential by dry anaerobic digestion of switchgrass-animal manure mixtures. Appl. Biochem. Biotechnol., 160, 965-975.

Alatriste-Mondragon, F., Samar, P., Cox, H. H. J., Ahring, B. K., \& Iranpour, R. (2006). Anaerobic codigestion of municipal, farm and industrial organic wastes: A survey of recent literature. Water Environment Research, 78, 607-636.

Amon, Th., Amon, B., Kryvoruchko, V., Bodiroza, V., Potsch, E., \& Zollitsch, W. (2006). Optimising methane yield from anaerobic digestion of manure: Effects of dairy systems and of glycerin supplementation. International Congress Series, 1293, 217-220).

APHA. (1995). Standard Methods for the Examination of Water and Wastewater. Washington, DC: American Public Health Association.

Budiyono, Widiasa, I. N., Johari, S., \& Sunarso. (2010). The kinetic of biogas production rate from cattle manure in batch mode. Int. J. Chem. Biol. Eng., 3, 39-44.

Deublein, D., \& Steinhauser, A. (2008). Biogas from waste and renewable resources. Weinheim, Germany: WILEY-VCH Verlag GmbH \& Co. KGaA, ISBN 978-3-527-31841-4.

Fantozzi, F., \& Buratti, C. (2009). Biogas production from different substrates in an experimental Continuously Stirred Tank Reactor anaerobic digester. Bioresource Technology, 100, 5783-5789.

Ferrer, I., Gamiz, M., Almeida, M., \& Ruiz, A. (2008). Pilot project of biogas production from pig manure and urine mixture at ambient temperature in Ventanilla (Lima, Peru). Waste Management, http://dx.doi.org/10.1016/j.wasman

Gerber, M., \& Span, R. (2008). An analysis of available mathematical models for anaerobic digestion of organic substances for production of biogas. Proceedings of International gas union research conference, 30 .

Hansen, K. H., Angelidaki, I., \& Ahring B. K. (1998). Anaerobic digestion of swine manure: inhibition by ammonia. Wat. Res., 32(1), 5-12.

Helffrich, D. \& Oechsner, H. (2003). The Hohenheim biogas yield test: Comparison of different laboratory techniques for the digestion of biomass. Agrartechnische Forsch., 9, 27-30.

Koppar, A., \& Pullammanappallil, P. (2008). Single-stage, batch, leach-bed, thermophilic anaerobic digestion of spent sugar beet pulp. Bioresource Technology, 99, 2831-2839.

Korazbekova, K. U., Bakhov, Zh. K., \& Saparbekova, A. A. (2013). Dry Fermentation of Agricultural Waste in the Modified Leach-bed Reactor with Immobilization of Microorganisms. Biotechnology, 12(6), 236-244.

Korazbekova, K. U., Bakhov, Zh. K., \& Saparbekova, A. A. (2012). Kachestvennye i kolichestvennye characteristiki obrazovania biogaza iz smechannych othodov. Nauka i obrazovanie Iujnogo Kazakhstana, 3/4(94/95), 186-192.

Labatut, R. A., \& Scott, N. R. (2008). Experimental and predicted methane yields from the anaerobic co-digestion of animal manure with complex organic substrates. Proceedings of the Annual International Neeting on ASABE, 8, 19-19.

Lay, J. J., Li, Y. Y., \& Noike, T. (1998). Mathematical Model for methane production from landfill bioreactor. $J$. Environ. Eng., 124, 730-736.

Li, J., Jha, A. K., He, J., Ban, Q., Chang, S., \& Wang, P. (2011). Assessment of the effects of dry anaerobic co-digestion of cow dung with waste water sludge on biogas yield and biodegradability. Int. J. Phys. Sci., 6, 3723-3732.

Liu, Y., Miller, S. A., \& Safferman, S. I. (2009). Screening co-digestion of food waste water with manure for biogas production. Biofuels, Bioprod. Bioref., 3, 11-19. 
Lo, H. M, Kurniawan, T. A., Sillanp, M. E. T., Pai, T. Y., \& Chiang, C. F. et al. (2010). Modeling biogas production from organic fraction of MSW co-digested with MSWI ashes in anaerobic bioreactors. Bioresour. Technol., 101, 6329-6335.

Ludington, D. (2006). Calculating the heating value of biogas. Ithaca, New York: DLtech, Inc. Retrieved from http://syreen.gov.sy/archive/docs/File/Articles/from\%20dr.abd\%20alrhman\%20alchyah/2/Heating_Value_of _Biogas. Pdf

Martins das Neves, L. C. M., Converti, A., \& Penna, V. T. C. (2009). Biogas production: New trends for alternative energy sources in rural and urban zones. Chem. Eng. Technol., 32(8), 1147-1153.

Monou, M., Pafitis, N., Kythreotou, N., Smith, S. R., Mantzavinos, D., \& Kassinos, D. (2008). Anaerobic co-digestion of potato processing wastewater with pig slurry and abattoir wastewater. J Chem Technol Biotechnol., 83, 1658-1663.

Ohl, S. (2011). Ermittlung der Biogas- und Methanausbeute ausgewählter Nawaro. Disertation. ISSN 0931-6264. Kiel.

Seadi, T. A., Rutz, D., Prassl, H., Köttner, M., Finsterwalder, T., Volk, S., \& Janssen R. (2008). Biogas Handbook. Denmark: University of Southern Denmark Esbjerg.

Ward, A. J., Hobbs, P. J., Holliman, P. J., \& Jones, D. L. (2008). Optimization of the anaerobic digestion of agricultural resources. Bioresource Technology, 99, 7928-7940.

Weiland, P. (2006). Biomass Digestion in Agriculture: A Successful Pathway for the Energy Production and Waste Treatment in Germany. Engineering in Life Sciences, 6(3), 302-309.

Weiland, P. (2010). Biogas production: Current state and perspectives. Applied Microbiology and Biotechnology, 85, 849-860. Xie, S. (2012). Evaluation of biogas production from anaerobic digestion of pig manure and grass silage. Ph.D. Thesis, National University of Ireland.

\section{Copyrights}

Copyright for this article is retained by the author(s), with first publication rights granted to the journal.

This is an open-access article distributed under the terms and conditions of the Creative Commons Attribution license (http://creativecommons.org/licenses/by/3.0/). 